Vol. 5, n 1 | 2001

Varia

\title{
State bureaucrats and local influence on the use of military troops for maintenance of public order in
} France and Prussia, 1889-1914

Anja Johansen

\section{(2) OpenEdition Journals}

Electronic version

URL: https://journals.openedition.org/chs/779

DOI: $10.4000 /$ chs. 779

ISSN: 1663-4837

\section{Publisher}

Librairie Droz

\section{Printed version}

Date of publication: 1 January 2001

Number of pages: $53-73$

ISBN: 2-600-00607-9

ISSN: 1422-0857

\section{Electronic reference}

Anja Johansen, "State bureaucrats and local influence on the use of military troops for maintenance of public order in France and Prussia, 1889-1914", Crime, Histoire \& Sociétés / Crime, History \& Societies [Online], Vol. 5, $n^{\circ} 1$ | 2001, Online since 02 April 2009, connection on 25 March 2022. URL: http:// journals.openedition.org/chs/779; DOI: https://doi.org/10.4000/chs.779 


\title{
State bureaucrats and local influence on the use of military troops for maintenance of public order in France and Prussia, 1889-1914
}

\author{
Anja Johansen'
}

Cet article compare les politiques divergentes de l'Empire allemand et de la Troisième République française en ce qui concerne le recours à l'armée, dans le domaine du maintien de l'ordre en cas de manifestation ou de conflit du travail, entre 1889 et 1914. Il soulève le point de savoir si l'utilisation croissante de la troupe durant cette période en France tient à l'incapacité du gouvernement central et des autorités départementales à contrôler l'utilisation par les municipalités de leur droit à requérir l'armée. L'article analyse le processus de prise de décision relatif à la réquisition des troupes et les relations entre les dirigeants de l'État, les groupes de pression locaux et les élites industrielles dans deux des régions industrielles les plus turbulentes: la province prussienne de Westphalie et la région française du Nord-Pas-de-Calais. Il conclut que les préfets étaient tout aussi capables et désireux que leurs homologues westphaliens de contrôler strictement les autorités municipales en matière d'intervention de l'armée pour le maintien de l'ordre. L'usage extrêmement fréquent de celle-ci en France ne peut donc être attribué à la faiblesse du gouvernement central et de son administration à l'égard des pouvoirs locaux.

The article compares the diverging policies in imperial Germany and in France under the Third Republic, between 1889 and 1914, of calling upon the army to police protest and labour conflicts. It asks whether the increasing use of military troops in France during this period reflects the inability of the French central government and departemental administration to control municipal authorities' use of their right to call upon the army. The article presents an analysis of the decision-making process concerning the requisition of troops as well as the relationship between the leaders of the state administration with local pressure groups and industrial elites in the two most turbulent industrial areas: the Prussian province of Westphalia and the French region of Nord-Pas-de-Calais. The article concludes that the French prefects were just as capable and willing as their Westphalian counterparts of keeping municipal authorities under strict control when it came to using the army as a force of internal order. The extremely frequent use of troops in France can therefore not be attributed to the weakness of the position of central government and its administration in relation to local forces.

1 Anja Johansen defended her doctoral dissertation in Modern History on Bureaucrats, Generals, and the Domestic Use of Military Troops: Patterns of civil-military Co-operation Concerning Maintenance of Order in French and Prussian Industrial Areas, 1889-1914 at the European University Institute in Florence in April 1999. She currently holds the post of Research Fellow at Clare Hall, Cambridge and is preparing her doctoral thesis for publication.

This article is a revised version of a paper presented at the European Social Science History Conference (Amsterdam, March 1998). It is partly based on my doctoral thesis (Johansen, 1998). 
$\mathrm{O}$ ne of the main themes of on-going research on policing in Western Europe is the process of de-militarisation of maintenance of public order during the nineteenth century. The take-over of internal peacekeeping by civilian police and gendarmeries, between 1870 and 1920, is particularly relevant in countries like France or Germany, where the army traditionally played a significant role as a force for internal order. While much attention has been paid to the development of police and gendarmerie in these two countries ${ }^{2}$, the role of the regular army in domestic peacekeeping after 1870 has scarcely been researched ${ }^{3}$. Due to the small amount of empirical research on the domestic role of the army of the German Empire and the French Third Republic, together with a lack of comparative perspective, little attention has been paid to the strikingly dissimilar development in the domestic use of military troops in the two countries: in the German Empire, the army came to play a very minor role in domestic peacekeeping between 1889 and 1914, while, during the same years, the French army became increasingly involved in the policing of labour conflicts and political protest.

Although the development in France can partly be accounted for by the instable social and political situation of the early Third Republic, for comparison of the conflicts occurring in the two countries as well as the conflicts to which the army was mobilised between 1889 and 1914 show that there was only partial correlation between the level of unrest and the response in terms of law-and-order measures. In fact, the vast majority of military interventions in France concerned very minor incidents of unrest or merely potential unrest. At the same time, given the significantly larger industries and comparatively well-organised workforce, the great labour conflicts that took place in Germany comprised many more strikers than the most extended conflicts occurring in France ${ }^{4}$.

The propositions in the literature are of little help in explaining why such dissimilar policies were pursued. The literature on policing in Germany generally agrees that the policy of de-militarising protest policing was the project of the Prussian Ministry of the Interior and the leaders of the provincial administration as

2 Liudtke (1982); Spencer $(1984 ; 1985 ; 1992)$ Funk (1986); Jessen (1991; 1992). In France, policing of the early Third Republic has been looked into primarily by Berlière $(1991 ; 1996)$, Bruneteaux (1993; 1996) and Carrot (1984).

3 The principal works on policing and maintenance of order in early Third Republic, Berlière (1991; 1996) and Bruneteaux $(1993 ; 1996)$ deal with the role of the army in a few pages. Carrot (1984) concentrates on legal and organisational aspects of maintenance of order, while Jauffret (1983), Bruneteaux (1993) and Berlière (1996) all focus on the political debates about the establishment of a specialised force to take over tasks of ensuring public order. As for the literature on maintenance of order in the German states, Lildtke's study (1982) concentrates on the first half of the century. Jessen $(1991 ; 1992)$ works on policing in Westphalia $1848-1914$, but deals only marginally with the role of the army. Klïckmann (1978) analyses the legal framework around military involvement, while Funk (1986), Henning (1987) and Deist (1991) focus on the policies of de-militarisation pursued by the Prussian Ministry of the Interior and War Ministry, with little attention to how these were implemented in practice.

4 Boll (1992); Johansen (1998). In Germany, the large miners' strikes mobilised 90000 miners in 1889,200000 in 1905, and 190000 in 1912. By contrast, even the most extended strikes in the French mining industry mobilised only 86000 in 1906 and 130000 in 1912 . In 1906, which was the most turbulent year in France, there were 438000 registered strikers, whilst in Germany there were 526000 registered strikers in 1905 and 481000 in 1912. Only the widespread protests in southern France during the summer of 1907 were joined by a larger number of people than any incident occurring in Germany. 
opposed to local forces calling for significant display of military force against strikers and demonstrators ${ }^{5}$. The attempts to avoid military involvement were justified with the argument that the army with its inflexible military means of repression was unfit for handling sensitive conflicts: soldiers lacked personal authority and could easily proceed to violent actions; moreover, the very presence of military troops posed a risk of provoking violent confrontations with protesters. Similarly, it was argued that the use of the national army against citizens created a risk of undermining the legitimacy of the State ${ }^{6}$. In the literature, the de-militarisation of the internal peacekeeping in Germany is thus explained with reference to a series of practical and ideological considerations. It is nevertheless worth noting that the same arguments were put forward in the French National Assembly, in the public debate, and by the French military establishment ${ }^{7}$; this was not, however, of much consequence since the army was called upon with increasing frequency. This is all the more surprising since the alleged negative effects of the use of the army were potentially more damaging for the liberal French Republic than for the comparatively authoritarian Prussian-German system ${ }^{8}$.

Interpretations of the domestic role of the army in France and Germany focus primarily on the governmental policies adopted for a few notorious incidents. This seems justified for Germany, where central government authorities became involved in almost all cases of domestic military intervention? ${ }^{9}$. In France, however, the focus on governmental actions in a few big conflicts does not take into consideration that the majority of incidents that triggered military intervention were rather limited conflicts comprising less than a thousand participants; moreover, the disturbance of the 'public order' was in many cases only potential.

The comparison of the diverging developments in France and Germany opens the question of who was responsible for the increasing use of troops for small-scale unrest. Given that, in both countries, the mobilisation of the army against protesters or striking workers was most often to the advantage of local political elites and industrial interests, the degree of local influence on the use of troops needs to be investigated. This article will therefore look at the question of whether the extremely frequent calls for military assistance in France was due - at least to some degree - to difficulties experienced by the French central government and provincial administration in controlling the municipal authorities' use of their legal right to request military protection. This question is all the more relevant since, in France as well as in Germany, the call for military protection had previously, in the $19^{\text {th }}$ century, been dealt with primarily between local garrison commanders and municipal authorities, which were closely connected with - if not entirely controlled by - local industrial elites ${ }^{10}$.

5 Henning (1987); Jessen (1991); Spencer (1985; 1992).

6 Funk (1986, pp.155-156); Jessen (1991, pp. 77-79); Spencer (1992, pp. 86-87).

7 Jauffret (1983, pp. 111-115); Bruneteaux (1993, pp. 33-35); Bruneteaux (1996, pp. 44-49).

8 As Hobsbawm argues, «Governments, especially those who had to worry about public opinion and their electors, were usually careful about facing troops with the risk of shooting down their fellow citizens, since the political consequences of soldiers firing on civilians were apt to be bad». Hobsbawm (1997, p. 305).

9 The miners' strike of 1889 and 1893; the Polish riot of 1899; the Mansfelder strike of 1909; the Westphalian miners' strike of 1912 and the Zabern Affair of 1913.

10 Lüdtke (1982) has demonstrated this for the furst half of the century. Similarly, Perrot (1975) shows the significant involvement of local elites in French labour confrontations during the period 1870-1890. 
The article looks at the two areas in France and Germany which had the highest frequency of military interventions between 1889 and 1914: the Prussian province of Westphalia, with the industrial areas around the Ruhr River, and the two French départements, 'Nord' and 'Pas-de-Calais'. It seeks to demonstrate that neither in Westphalia nor in Nord-Pas-de-Calais was the use of troops shaped by direct or indirect actions from local politicians, pressure groups or industrial magnates. In fact, in Nord-Pas-de-Calais as well as in Westphalia, it was the most senior state administrators at the départemental or provincial level, who came to be entirely in charge of decisions concerning the use of troops through effective exclusion of municipal authorities. Moreover, the case study shows that, in both areas, the senior state administrators were in a position to implement policing measures against the explicit wishes or vigorous protests from local politicians and pressures groups.

\section{THE DISSIMILAR DEVELOPMENTS IN THE DOMESTIC ROLE OF THE FRENCH AND THE PRUSSIAN ARMIES}

Until the $1880 \mathrm{~s}-1890 \mathrm{~s}$, military troops had played a significant role in the implementation of law-and-order measures in both France and Germany, and in many areas it was the only law enforcement agency. During the 1870 s, voices within the French and German military establishments as well as the left wing opposition began to raise questions about the future role of the army as a force of internal order. However, it was only in the 1890 s that the domestic role of the army became a political issue and the practices in the two countries took diverging trajectories.

In Germany, the policy of de-militarisation of maintenance of order emerged in the wake of the great miners' strike of 1889 . Between 1889 and 1914, a mere twenty-seven incidents are recorded by the Prussian War Ministry and Ministry of the Interior in which military troops were either mobilised or simply kept ready to intervene to maintain or restore public order ${ }^{11}$. As for Westphalia, troops were mobilised on only three occasions between 1889 and $1914^{12}$.

In France, attempts to limit the role of the army as a force of internal order were made in Paris after 1893, when Louis Lépine became police prefect. Although Lépine aimed at handling most situations with police and gendarmerie alone, he still requested military assistance on numerous occasions to control demonstrations ${ }^{13}$. Outside Paris military troops were used with increasing frequency from the late 1880 s until after the First World War. Contemporary observers and historians have been split in their judgement of successive governments' use of troops. Interior Ministers and heads of government, from Freycinet to Clemenceau and Briand, justified their use of military troops by the necessity of using strong measures to maintain the authority of a fragile republican regime, particularly after the Dreyfus Affair, when the regime was challenged by both from the revolutionary left and the anti-republican right. If indeed there was in France a tradition for violent

11 These cases take in the entire German Empire except Bavaria. A slightly higher figure is reached by Richard Tilly. By scrutinising the German press, he identifies forty-eight incidents for the entire German Empire from 1882 to 1913 . Tilly, Tilly \& Tilly (1975, p. 226).

12 The great miners' strike of May 1889, the riots in Herne in 1899, and the miners' strike of March 1912.

13 Berlière (1993 a et b). 
protest $^{14}$, the ways in which the army was used on several occasions between 1901 and 1914 could only be described as resulting from the determination of successive governments to break the power of the trades unions and the Catholic Church ${ }^{15}$. The role of the army included not only repeated bloody intervention against strikers ${ }^{16}$, but also the use of conscript soldiers as strike-breakers ${ }^{17}$ and highly inventive interpretation of the military legislation by which striking rail workers were sent back to work $^{18}$.

These incidents are only the tip of the iceberg, however; the use of soldiers for domestic purposes went much further. Alone in the two départements, Nord and Pas-de-Calais, the army was called upon on no less than seventy-eight occasions between 1889 and $1914^{19}$. Apart from major strikes or politically sensitive events (political protest, religious processions), the majority of incidents for which soldiers were mobilised were simple public gatherings of a large number of people, where the challenge to the public order was and remained 'potential' (e.g. visits of VIPs; public executions, public festivals, fairs, horse races or air shows).

If troops were called upon more frequently in Nord-Pas-de-Calais than in Westphalia, this was not because the French authorities had fewer police and gendarmerie forces at their disposal. Apart from the army, there were three types of forces of public order. Urban communities were policed by municipal police forces under the authority of mayors, or city mayors in larger towns. By 1889, the ratio of inhabitants per municipal policeman in the industrial cities of the Ruhr was inferior to the standards of French towns, including the industrial cities in Nord-Pas-deCalais ${ }^{20}$. Although the number of municipal policemen in Westphalia increased significantly between 1889 and 1914, the rapid growth of the population in the industrial cities largely neutralised the increase in municipal police forces; and by the outbreak of the First World War, the industrial towns in Nord-Pas-de-Calais were still generally better provided with municipal policemen compared to the population than the Westphalian towns.

The supplementary forces were also crucial for the maintenance of order. In both Prussia and France, the gendarmerie, primarily in charge of policing rural areas, also functioned as an additional force to be mobilised to any part of the country in case of major unrest. In addition, there were the state police. The Prussian state police

14 Tilly (1986); Moscovici (1981); Erlanger (1968, pp. 356-370); Wormser (1961, pp. 211-225).

15 Agulhon (1990, p. 219); Serman (1982, pp. 58-63); Rebérioux (1975, pp. 111-113); Julliard (1965).

16 Nine striking workers were killed at Fourmies in 1891; in 1900, three were killed at Chalon-surSaône, whilst another three strikers were killed at Longwy in 1905 ; two demonstrators were killed in the widespread protests during the spring of 1906 , and six were killed during the protests in southern France in the summer of 1907; finally, six strikers were killed at Draveil-Vigneux and Villeneuve-Saint-Georges in 1908.

17 In 1907, during a strike among electricians, soldiers were ordered to replace the strikers in order to ensure the basic service; this also happened during a major strike among postal workers in 1909 and a strike among gas workers in Tourcoing in 1911. Similarly, during a strike among dustmen in Lille, soldiers were called out to remove the rubbish.

18 During a nationwide strike among rail workers in October-November 1910, many of the strikers were called up as army reservists and then sent back to work as soldiers under military law.

19 This is only a minimum figure. The actual number is likely to be significantly higher (Johansen 1998).

20 Comparison based on the figures provided by Jessen (1991), Carrot (1984), and Berlière (1991 ; 1996). 
(the Royal Guards), not only policed an increasing number of cities, they also functioned as a supplementary force of riot police. However, the Prussian state police together with the Prussian gendarmerie comprised only 22500 men on the eve of the First World War, whilst the French gendarmerie alone constituted a force of 26000 men. Moreover, there were in France 5000 Republican Guards and 8 000-10 000 state police operating in Paris, Lyon and, from 1908, in Marseille as well. Thus, both in total numbers and in proportion to the population, French towns and rural areas were better provided with police and gendarmerie.

\section{MUNICIPAL AUTHORITIES AND THE CONTROL OF CIVIL AND MILITARY FORCES OF ORDER}

The police, the gendarmerie and the army were the instruments for implementing very restrictive definitions of 'public order'. According to both French and Prussian legislations, gatherings in public without special permission from a public authority could at any time be declared illegal by the police authorities ${ }^{21}$. Thus, any public manifestation (spontaneous or organised gathering, meeting or protest march) could be broken up by the police without further explanation. In Germany, traffic regulations were also frequently used to force people away from streets and squares. By 1890, the workers' right to organise and to strike was recognised in both countries; however, severe restrictions were imposed on the actions of striking workers. The police and gendarmerie were supposed not only to intervene against attacks on strike-breakers and sabotage against private property, but also to impede picketing, marches or the gathering of strikers in front of their workplace. Similarly, law-and-order measures could also be used to prevent strikers from trying to make workers from other companies join the action. Influence over the policing measures was therefore a major resource in the contest of strength between employers and employees.

In Westphalia, the employers clearly had the upper hand. Due to the Prussian three-class voting system, Westphalian municipal authorities were almost entirely controlled by the wealthy bourgeoisie, whereby the industrial elites kept a firm grip on the use of municipal police forces. At the same time, mining companies and factory owners could implement their own measures to ensure order at their plant or factory through private security corps or even privately hired gendarmes ${ }^{22}$. In event that labour conflicts went beyond the municipal borders, policing measures were established in close cooperation between municipal authorities and the state administration, which was in charge of the distribution of Royal Guards and gendarmes between the municipalities. Mayors of the main industrial towns thereby acquired influence on the policing measures of not only their own town but indeed of the wider district and province. Thus, the connection between capital interests and policing was conspicuous. As for requisition of military troops, both French and Prussian legislations formally empowered municipal authorities to call upon the army. Within the Prussian system, the army could be approached at four levels: by

21 The French law of 7 June 1848 on gathering in public; the Prussian law of 30 December 1798 on police and military intervention, and the Prussian law of 11 March 1850 on police administration. 
the state governor of a province (Oberpräsident), of a district (Regierungspräsident), or of a county (Landrat); at the municipal level, the army could be called upon by the mayor, the city major, or by the municipal police master ${ }^{23}$. However, in the event of military involvement, the direct influence on policing measures disappeared because all authority over civilian as well as military forces was then transferred to the military authorities ${ }^{24}$.

Even if the French system also placed the local police and gendarmerie under the municipal authorities, French mayors were more easily challenged in their position than their Prussian counterparts because their authority over the local police and gendarmerie could be withdrawn at any moment by the prefect $^{25}$. As in the Prussian system, French legislation granted the right to call upon the army to a series of public officials at the municipal level: the mayor, the mayor's assistant, as well as any police officer or gendarme $e^{26}$. However a requisition issued by any of these authorities could at any time be invalidated either by the sub-prefect at the level of arrondissements, or directly by the prefect. Once the prefect took over the responsibility for law-and-order measures, the mayors were stripped of their authority over any police measure. French municipal authorities could therefore implement lawand-order measures only as long as the prefect did not intervene.

Until the $1880 \mathrm{~s}-1890 \mathrm{~s}$, when protests in Westphalia and Nord-Pas-de-Calais rarely exceeded the municipal boundaries, rarely lasted for more than an few days, and seldom comprised more than a couple hundred protesters, decisions to call for military troops were generally taken by the mayor together with the local police master, and requisitions were addressed directly to the commander of the nearest garrison $^{27}$. When comparing the dissimilar development of the use of troops in France and Germany, it is worth noting that, during the 1890s, the municipal authorities in Westphalia as well as in Nord-Pas-de-Calais were effectively hindered in using their formal right to call upon military assistance. Instead, decision-making concerning involvement of the army as well as contact with the military authorities became concentrated at the level of Oberpräsidents and Regierungspräsidents, in Westphalia, and by the prefects, in Nord-Pas-de-Calais.

\section{CONCENTRATION OF DECISION-MAKING IN WESTPHALIA}

Formally, the heads of the provincial state administration never succeeded in obtaining that requisitions for military assistance pass through them ${ }^{28}$; nor could an Oberpräsident or a Regierungspräsident intervene against a requisition issued by a

23

Law of 30 December 1798; Prussian Constitution of 31 January 1850, Article 36.

Cabinet Order of 17 October 1820.

Law of 5 April 1884 on municipal powers, Article 99.

Laws of 27 July-3 August 1791; Instructions of 20-31 August 1907 on the requisition of military troops.

Lüdtke (1982); Girardet (1953). Even for very serious matters such as the declaration of a military state of siege in Bielefeld 1885, these were the decision-making authorities.

According to a governmental instruction of 31 December 1825 , the requisitions were supposed to go through the Oberpräsident, but this rule had never been seriously enforced. The Prussian Constitution of 31 January 1850 stated that troops could be requested by the 'civilian authorities' without specifying. 
local authority and followed by a military commander because, the moment a requisition was issued by a competent authority, any decision to end the military involvement depended on the army authorities. After the turn of the 20th century, examples can still be found of mayors or police masters addressing requisitions directly to a local garrison commander ${ }^{29}$. However, if the senior state administrators failed in their attempts to prevent local authorities from issuing requisitions, the execution of these were effectively obstructed by succeeding army-corps commanders, who forbade their subordinates mobilising troops without their explicit order.

By the great Westphalian miners' strike of 1889 , the initial requisitions were still issued by mayors, police masters or the Landrat. However, in May 1889, due to the extent of the conflict, involving a large number of administrative units, the co-ordination and management of law-and-order measures were soon taken over by the Oberpräsident and the army-corps commander of the Westphalian province. After 1889 , some of the senior commanders became increasingly reluctant to deliver troops to act as an extended police force. Fighting against unarmed workers in the streets was not considered appropriate for a professional army and was regarded as degrading for the prestige of the army ${ }^{30}$.

Accordingly, successive army-corps commanders began to complain about requisitions from local authorities. The desire to limit the use of the army for maintenance of order was strongly expressed by General von Albedyll, who had been responsible for the 1889 military intervention in Westphalia. After the end of the strike, he declared, in a letter to the Kaiser, that the use of the army as an extended police force needed to be strictly limited; otherwise the army would spend all their time and resources on policing internal conflicts ${ }^{31}$. Similarly, the army-corps commander in the Rhine Province, General von Loë, describes the ordinary procedure concerning requisition of troops as being that the Landrat, the Regierungspräsident or the Oberpräsident addressed their requisitions directly to the army-corps commander. Only in exceptional situations with special permission from the army-corps commander, could a Landrat be allowed to issue a requisition directly to the nearest garrison $^{32}$. General von Loë, like General von Albedyll, complained that local authorities deliberately exaggerated problems and that the officers wasted time and energy coming to rescue municipal police forces when there was no real threat of serious trouble ${ }^{33}$.

Therefore, if army-corps commanders agreed with the Westphalian Oberpräsidents about one thing, it was to keep the mayors' and police masters' use of their right to requisition under strict control. During the following decade, senior

29 Jessen (1991, pp. 133-134).

30 In 1895, when provoked by Bebel, War Minister Walter Bronsart von Schellendorff declared in the Reichstag that the army preferred to fight a foreign enemy rather than being involved in dishonouring street-fights against striking workers. Similarly, during the Hamberg dockers' strike 1896-1897, General von Waldersee expressed his displeasure at letting his men fighting in the streets against hungry workers. Waldersee (1922) diary notes of 2. December 1896.

31 Münster Hauptstaatsarchiv (MHStA), OP 2847b, documents 8-9. Letter of 1 July 1889 from General von Albedyll to William II.

32 Letter of 24 April 1890 from General von Loë to General von Waldersee. Waldersee (1927, pp. 367$368)$.

33 Letter of 24 April 1890 from General von Loë to General von Waldersee. Waldersee (1927, pp. $367-$ 368). Letter of 11 March 1889 from General von Albedyll to General von Waldersee. Waldersee (1927, pp. 288-289). 
commanders increasingly insisted on leaving no room for local decision-making when the army were involved and would accept being approached by civil authorities only at the level of the Oberpräsident or Regierungspräsident. The same determination was shown by General von Bissing in 1904, when the Westphalian Oberpräsident and the Minister of the Interior suggested that civil and military authorities should determine in advance to which garrison each Landrat in the Ruhr area were to address a requisition in the case of extreme urgency. The army-corps commander refused even to consider the question, arguing that allowing requisitions to be made at the level of the Landrat directly to a local garrison was a blow to his authority as army-corps commander ${ }^{34}$. General von Bissing insisted that, if a local military commander received a requisition from a Landrat or mayor, he had to ask the army-corps commander for permission to mobilise. As army-corps commander, General von Bissing would then contact the Oberpräsident in order to check the seriousness of the case and the appropriateness of intervening with military troops. The Oberpräsident could then issue a requisition by his own authority or leave it to the military apparatus to refuse delivering the requested troops.

Accordingly, bureaucratic procedures developed whereby the order to mobilise troops came from the army-corps commander only after having been requested directly by the Oberpräsident or a Regierungspräsident. This pattern can already be observed in practice in June 1899, when the army intervened against rioting Polish miners in Herne. Only when a requisition was issued by the Oberpräsident, did the general commander, von Mikush-Buckberg, send troops to the area under the command of a colonel, who then determined the details in consultation with the mayor of Herne and the local police authorities. On the occasion of the miners' strike of 1912, local pressures to call for military assistance were addressed to the Regierungspräsidents of Arnsberg and of Münster. However, it was only when these two senior administrators, together with the Oberpräsident of Westphalia, decided to issue a requisition that contacts were taken to the military authorities. The effectiveness of the bureaucratic obstructions through the military hierarchy can be seen from the few incidents of military intervention that took place after 1889, despite requests from mayors or local police authorities for military protection. It is also worth noting that, during the miners' strike of 1905 , the senior state administrators were capable of obstructing military intervention against the clear wishes of numerous municipal authorities.

\section{THE PREFECTORAL TAKE-OVER OF LAW-AND-ORDER MEASURES IN NORD-PAS-DE-CALAIS}

Against the background of the more frequent use of troops in Nord-Pas-deCalais compared to Westphalia, it is important to note that, in Nord-Pas-de-Calais, a similar transfer of authority from municipal authorities to the prefect can be observed during the 1890 s.

Contrary to the Germany system, the institutional marginalisation of the municipal authorities in questions concerning requisition of military troops was not due to

34 MHStA, OP 6095, document 71. Letter of 6 April 1906 from General von Bissing to the Oberpräsident of Westphalia. 
military obstruction. Even if members of the French military establishment did have professionally motivated reservations about their role as an extended police force ${ }^{35}$, they were not in a position to effectively obstruct this use of the army, since French military commanders at all levels were obliged, under criminal law, to follow a requisition issued by any competent civil authority ${ }^{36}$. By contrast, the prefect was empowered to invalidate or modify requisitions issued by any municipal authority ${ }^{37}$. No military intervention could therefore take place against the prefect's will. During the $1890 \mathrm{~s}$, prefects increasingly tended to take over law-and-order measures concerning any potentially sensitive situation. Contrary to Westphalia, where municipal authorities had some influence on law-and-order measures through their cooperation with the Oberpräsident and Regierungspräsident, in Nord-Pas-de-Calais, the intervention of the prefects always meant exclusion of municipal authorities and local police forces.

There were several reasons for the increasing tendency of the prefects in Lille and Arras to take over the responsibility for law-and-order measures, particularly when the army was involved. In the widest perspective, the prefectoral take-over of law-and-order measures has to be seen against the background of the fragile political position of the republican regime during and after the Dreyfus Affair. Challenged both from the anti-republican right and from the trades unions on the left, both the central government and the regional administration became very eager to propose what they perceived as necessary measures to keep unrest under control. The municipal police was seen by the state administration as too weak and incompetent to effectively ensure public order and manage sensitive situations ${ }^{38}$; prefects therefore generally preferred to rely on the gendarmerie - and to an increasing extent also on the army.

The lack of confidence in the strength and professional capacities of the municipal police was paired with the suspicion that the actions of municipal police were strongly biased towards the wishes of whoever was in charge of city hall. This problem was particularly acute in Nord-Pas-de-Calais, where the political orientations varied significantly between municipalities dominated by a conservativeminded bourgeoisie of notables supported by the industrial elites, and municipalities with a population consisting primarily of industrial workers, where the prevailing political forces were radical or socialist. In municipalities controlled by conservative forces, any form of protest would often be met with heavy-handed police intervention. This blatant lack of neutrality on the part of the local police was a problem for the prefect, in particular when he was called to arbitrate in labour conflicts. Accordingly, the take-over of law-and-order measures by the prefect was often justified by the importance of appearing credible as an impartial negotiator. Similar problems of biased police actions existed in municipalities controlled by radical or socialist mayors. The French state formally guaranteed the protection of persons and property, and the free exercise of a profession. In labour conflicts, this meant protecting property and plant installations against sabotage as well as protecting strikebreakers against picketing strikers. Given the constant accusations from

35 Jauffret (1983); Serman (1982, pp. 45-63).

36 French Criminal Code Article 114.

37 Law of 5 April 1884 on municipal authorities, Article 99.

38 Berlière (1996) p.23. 
anti-republican forces that the Republic equalled chaos and anarchy, it was essential for the central government and its administration to demonstrate their preparedness and ability to protect both private property and strike-breakers. In municipalities where radicals or socialists were in charge of city hall, the tendency of the local police to show a rather lenient attitude towards the actions of striking workers fuelled these accusations. Suspicious of the political neutrality of municipal police forces, the prefects often preferred to take over the responsibility for law-and-order measures in sensitive conflicts.

Similarly linked to the fragmented political landscape between municipalities, was the problem of consistency in policing measures when a conflict extended to other areas. Strikes in the major industrial sectors (mining, textile, construction or transport) would typically concern a great number of companies or factories within a wide territory covering several municipalities, many of which were not directly affected by the strike. Groups of striking workers would often move from one area to another, trying to make the workers of other mines or factories join the conflict. A major strike would therefore directly or indirectly affect the majority of municipalities within the district. In situations of conflicts going beyond the municipal boundaries, the mayors' right to call for military protection became particularly detrimental; some mayors would call for military protection, while others would do their best to implement only the most basic policing measures, depending on the political majority within each community. The only way of avoiding total chaos, when a conflict extended over several municipalities, was for the prefect to strip the municipal authorities of their authority over the municipal police and take charge of all law-and-order measures ${ }^{39}$. When the prefect took over the law-and-order measures, he had to face criticism both from mayors complaining that the policing measures were insufficient, and from mayors protesting vigorously against the sending of gendarmes or soldiers to their community ${ }^{40}$.

On the other hand, when it came to involving the army, the prefect's position was strengthened by increasing reluctance of municipal authorities to use their formal right to request military protection directly from the local garrison. There were both political and financial reasons for this. Mayors who built their political position on the wealthy notables were under strong pressures from their electorate to call for effective protection against riots in the streets; they were constantly at risk of being criticised for not having done enough if a situation got out of control, and citizens with property might demand compensation if their property was damaged. On the other hand, not only striking workers but also groups not involved in the conflict tended to complain about the expense and consider the call for the army to be a costly and exaggerated measure. All mayors, irrespective of their political orientation, were confronted with the problem that, no matter which law-and-order measures they implemented, the municipality were at risk of ending up with a huge bill: according to the 1884 law on local government, municipal authorities were not only obliged to finance a local police force, but were also financially responsible for

39 Haupt (1986, p. 246); Cooper-Richet (1987, p. 409).

40 In October 1902, for instance, when the miners from the entire region went on strike, the mayor of Bethune and the surrounding suburban municipalities urged the prefect of Pas-de-Calais to request military assistance. On the other hand, the mayor of Avion, who was from the French Labour Party, as well as the socialist mayors of Lens and Denain, protested vigorously against the idea of military intervention and threatened to resign if troops were called upon. 
damages to public and private property if the mayor had not used all his legal resources to ensure the maintenance of public order ${ }^{41}$. Even left-wing mayors therefore had to weigh the costs of protection against the costs of covering the possible damages in case of violent attacks on public and private property. If, by contrast, gendarmes or troops were mobilised on the initiative of the prefect, it was the French state that became financially responsible both for the extra wages to the officers and for possible damages to public and private property ${ }^{42}$. Then the municipalities had only to provide accommodation and food for the men and horses. Mayors who wanted to obtain military protection therefore often did not call directly upon the army, but instead sent petitions to the prefect, stressing the seriousness of the conflict and the potential for violent riots.

Thus, in Nord-Pas-de-Calais as in Westphalia, the requisition of troops as well as the contact with the military authorities moved from the municipal authorities to the senior representative of the central government at the regional level. The bureaucratic exclusion of municipal authorities from making use of their formal right to call for the army was coupled with increasing hesitation on the part of municipal authorities to make use of their right to request military assistance.

\section{WESTPHALIAN OBERPRÄSIDENTS AND LOCAL ELITES}

With the concentration of decision-making in the hands of the Oberpräsident and Regierungspräsidents, what was the context in which these senior administrators decided to handle maintenance of order with police and gendarmerie alone or to request military assistance? In Westphalia, the policing measures implemented in labour conflicts by the state administration and judiciary strongly supported the interests of employers and the local elites that dominated the majority of municipalities. Nevertheless, the involvement of the army in the policing of social conflicts generally marked the limits of the extent to which the senior administrators in Westphalia were willing to go in their support of industrial interests.

At every major strike in the mining and steel industry, pressures would be placed on the government and the state administration to mobilise the army. The pressures from industrialists, however, rarely proved successful. It is worth noting that the senior administrators in this issue were up against powerful forces because, with the increasingly extended and long labour conflicts of the 1890s, the costs of military protection became so great that only industries with strong financial capacities could afford to pay for military protection. Already by the time of the 1889 strike, the powerful employers' association appealed in vain to the government about declaring a state of siege, although many of the strikebound mines - particularly those in the Saarland - were owned and run by the state ${ }^{43}$. During the 1890 s, even the otherwise very powerful Central Association of German Manufacturers - representing heavy industry and mining - faced increasing difficulties in persuading the heads of the provincial administration to provide military protection for their plants and workers. Similarly unsuccessful were the attempts of individual mining companies to obtain

41 Law of 5 April 1884 on municipal powers, Articles 106 and 108.

42 Decision from the State Council of 6 July 1893 ; Berlière (1996; p. 83).

43 Spencer (1992, pp. 86-87). 
permanent military guards at their plants or frequent military patrols ${ }^{44}$. In 1905 , the mining companies appealed in vain to the provincial governor of Westphalia and directly to the government to provide an impressive show of military force, and by the time of the great miners' strike in March 1912, troops were mobilised only when the senior state administrators saw no other way of preventing violence and riots, even if the mining companies had sought to obtain military protection before the conflict broke out ${ }^{45}$.

The repeated refusal to accommodate the needs of industrialists indicates the strong position of senior state administrators in relation to industrial pressure groups. Senior state administrators were appointed by the Minister of the Interior and were responsible only to the government in Berlin. As members of the Prussian civil service, they also tended to display a very assertive attitude towards local elites and locally elected authorities, particularly when these were bourgeois rather than traditional landed nobility ${ }^{46}$. Confronted with demands for military protection for employers in labour conflicts, senior state administrators were often eager to demonstrate that their decisions were independent from private and capital interests $^{47}$.

At the same time, a change of attitude towards labour conflicts can be seen among state administrators after the miners' strike of 1889 . In 1889 , the prevailing attitude among civil servants had been that strikes were unacceptable and that a forceful response to any form of public disturbance was the only appropriate way of dealing with it. In 1889 there seem to be few senior bureaucrats, like the Regierungspräsident in Düsseldorf, von Berlepsch, who saw the intransigent attitude of the mine-owners and their demand for military protection as an unreasonable pursuit of particular interests that put public order at risk and exposed the entire community to the threat of violence and riots ${ }^{48}$. After the turn of the 20 th century, however, this attitude is clearly discernable whenever military intervention was discussed. Scholars have noted that, during the miners' strike of 1905 , senior civil servants expressed a certain sympathy and understanding for the workers' complaints, which they recognised as reasonable and justified ${ }^{49}$. At the same time, their criticism of the private companies for being irresponsible in their provocation of labour confrontations became more pronounced. In 1905, the reports from the senior state administrators to the Ministry of the Interior showed a significant degree of exasperation with companies whose actions deliberately obstructed the policing mea-

44 Geheimes Staatsarchiv, Berlin-Dahlem (GSBD) H.A.1. - Rep.77-Titel 2513, 1) Beiheft 2. Letter of 13 May 1889 from the Landrat in Gelsenkirchen to the Minister of the Interior.

45 GSBD, H.A 1 - Rep.77 - Titel 2523, 1), vols. 11-12.

46 The studies on elite structures among bourgeois elites of the Rhineland and Westphalia all indicate that the industrialists as well as businessmen had few social connections to the state administrators at the local and provincial levels. Pierenkemper (1979); Augustine (1993, p.69); Kaudelka-Hanisch (1993, pp. 89-90). Similarly, my own research on the social acquaintances of the military elite at the provincial level show that industrialists and bourgeois notables were virtually excluded from informal access to the military commanders. The relationship of Alfred and Fritz Krupp with senior generals was a notorious exception to this rule. Johansen (1998, pp. 151-156).

47 Born (1957, p. 82-84); Henning (1987, p. 141-152).

48 Berlepsch (1925, pp. 19-25).

49 Born (1957, pp. 184-185); Spencer (1984, p. 102). 
sures being taken by the state administration ${ }^{50}$, and stressed the importance of keeping the municipal authorities' use of troops under strict control ${ }^{51}$. In their justifications to the Ministry of the Interior for their refusal to yield to pressure from the mining companies, the Regierungspräsidents of both Münster and Düsseldorf declared that they did not see any reason for believing the descriptions of widespread violence and riots put forward by the mining companies, and claimed that the requests of the mining companies for military protection were irresponsible and described their request for forces as highly unrealistic ${ }^{52}$. The exasperation with industrialists and mayors, however, was not discernible on this occasion alone. In March 1912, even though troops were eventually mobilised, the senior administrators still saw industrialists and mayors as working for their own particular interests, while disregarding the need for a peaceful settlement of the conflict $\mathrm{t}^{53}$.

As long as senior administrators were supported in their priorities by the Ministry of the Interior and by the general commander in charge of the military organisation in the province, it was possible to withstand the pressures from powerful industrial groups. Rather than simply following the needs of industrial elites, the army was called upon only when senior state administrators considered that the stability of wider society was threatened by a strike movement which vastly overextended the capacities of the police and gendarmerie forces (i.e. the miners' strikes of 1889 and 1912) or protest from groups that were considered to be a serious challenge to the existing social and political order (e.g. social-democrat demonstrations; riots by Polish workers).

\section{LOCAL PRESSURES AND THE EXTENT OF PREFECTORAL AUTHORITY}

In Westphalia pressure from industrial organisations could be resisted because Prussian senior administrators, backed by the Ministry of the Interior, were in a position to refuse such demands. This opens the question of the degree to which lawand-order measures implemented by the prefects in Lille and Arras were shaped by informal pressures placed on the prefects by local politicians and industrialists. The interpretations of the degree of local influence on maintenance of order during this

50 One senior administrator reported how a mine-owner had declared that it was better not to close the local inns during the strike because drunken miners were most likely to proceed to violent actions, and once bloody confrontations had taken place, the state was forced to send in the army. GSBD, H.A 1 - Rep.77 - Titel 2523, 1) vol. 11. Letter of 20 February 1905 from the Regierungspräsident in Münster to the Minister of the Interior.

51 GSBD, H.A.1 - Rep. 77 - Titel 2523, 1), vol. 12 (documents 2-3). Letter of 23 January 1905 from the Regierungspräsident in Münster to the Minister of the Interior. Ibid. (documents 19-20). Letter of 23 January 1905 from the Regierungspräsident in Münster to the König Ludwig mining company.

GSBD, H.A.1. - Rep. 77 - Titel 2523, 1), vol. 11 (documents 213-214). Letter of 18 January 1905 from the Regierungspräsident in Münster to the Minister of the Interior. Ibid. (document 185). Telegram of 19 January 1905 from the Regierungspräsident in Dusseldorf to the Minister of the Interior. Ibid. (documents 269-271). Letter of 20 February 1905 from the Regierungspräsident in Münster to the Minister of the Interior.

53 In their daily reports to the Minister of the Interior, complaints were raised from the state administrators about the exaggerated descriptions from mayors and the need to keep their law-and-order measures under strict control. GSBD, H.A.1 - Rep.77 - Titel 2523, 1) vols.17-18; MHStA, Regierung Münster, VII-14, vol.37-3, 'Tagesberichte der Unterbehörden'. 
period are split between those who stress that the strong position of the central power enabled them to impose law-and-order measures ${ }^{54}$ and those who note that the prefects' sphere of action was limited by the need of weak governments to ensure support from local representatives in the National Assembly ${ }^{55}$. A close analysis of the patterns of military intervention in Nord-Pas-de-Calais seems to confirm that, in questions concerning maintenance of order, the prefects were in a position to impose their policing measures against significant opposition from local pressure groups.

To be sure, prefects of the early Third Republic were often exposed to all kinds of pressures from local representatives : deputies, senators, mayors, and members of the regional council, (conseillers généraux) ${ }^{56}$. Generally, the position of the prefects of the Third Republic was highly uncertain, and they were easily removed from the post or were transferred to another département, particularly on the frequent occasions of a change of Minister of the Interior. At the same time, in order to perform efficiently as the government's executive representative in a département, it was essential for the prefect to enjoy a reasonable degree of goodwill among the locally elected representatives. Due to the general governmental instability of the Third Republic and because of the ever-changing and fragile alliances in the National Assembly, the deputies - who were often also mayors in the most important towns sometimes put pressure on prefects by threatening to withdraw their support for the government ${ }^{57}$.

Against this background, it is worth noting that no change of prefect in the two départements, Nord and Pas-de-Calais can be linked to uncontrollable escalation of conflicts or bloody confrontations between public forces and civilians. Although there were repeatedly strong protests from local groups against the law-and-order measures implemented by successive prefects, the Nord and Pas-de-Calais show a remarkable degree of prefectoral stability. Together with the département of the Seine, these two départements had the highest degree of prefectoral stability between 1877 and $1958^{58}$. Despite a national average of fewer than four years in service for prefects in the period between 1876 and 1918, among the prefects who served in Pas-de-Calais between 1883 and 1918, all but one served seven years or more. Apart from the years 1897-1899, a similar pattern of prefectoral stability can be observed in the Nord. Moreover, one can observe that in several cases the same prefects served first in Pas-de-Calais and were then promoted to the particularly difficult département Nord ${ }^{59}$. The remarkable degree of prefectoral stability indicates that succeeding Ministers of the Interior were more inclined to maintain a strong

54 Carrot (1984); Berlière (1996).

ss Bruneteaux (1993; 1996); Wright (1994). This aspect is sustained by Chapman (1955) and SiweckPouydesseau (1969) in their studies on French prefects of the early Third Republic.

56 Wright (1994, pp. 298-299); Siweck-Pouydesseau (1969, pp.35-38); Chapman (1955, pp. 49-54).

57 Siweck-Pouydesseau (1969, pp. 35-38); Chapman (1955, pp. 49-54).

SB The départements Nord and Pas-de-Calais had, respectively, eighteen and nineteen prefects between 1877 and 1958. This had to be compared to an average number of prefects in a French département of 30.6. The most unstable départements (Corse and Tarn) both had 45 prefects between 1877 and 1958. Siweck-Pouydesseau (1969, pp. 60-64).

59 Vel-Durand served fourteen years altogether in the region, Alapetite and Trépont served for a total of ten years each, and Louis Vincent remained prefect in Nord during the twelve most turbulent years of the recent history of this département, between 1899 and 1911 . 
prefect, someone who could impose himself in a difficult region, rather than to sacrifice him for the sake of political alliances in the National Assembly ${ }^{60}$. With the support of the Minister of the Interior, the prefects seemed to be in a sufficiently strong position to impose their measures even against vigorous protests from local authorities and representatives.

Similarly, a highly consistent pattern can be observed in the prefects' use of military troops. If the use of troops to police strikes and popular protest had been heavily influenced by pressures from local representatives, one would expect a pattern in which the policing measures changed significantly from one conflict to another. By contrast, the high level of consistency indicates that, even if some mayors called for strong measures against disturbers of the public order, while others repeatedly protested against the use of the army against strikers and demonstrators, the prefect was capable of imposing his measures. Given that mayors of the larger towns were often also deputies in the National Assembly and had the potential to act directly on governmental policies, is all the more surprising that the dramatic increase in the number of military interventions occurred during the centre-left governments after 1899; these governments depended more than any previous government on the support of political groups that were the most likely to oppose military intervention. Despite repeated vigorous and widespread protests against the way in which troops were used in the contest of strength between the government and the trades unions as well as the implementation of anti-Catholic legislation, the prefects, backed by successive Ministers of the Interior, managed to impose highly unpopular policing measures ${ }^{61}$.

Finally, if prefects called upon the army in order to accommodate the needs of particular pressure groups, this should be discernible in a bias towards particular types of conflicts. In Nord-Pas-de-Calais, however, troops were called for all types of conflicts of all sizes. Large-scale strikes in crucial industrial sectors (e.g. strikes among miners, dock workers, rail workers or major confrontations in the textile industry) and politically sensitive events (e.g. political demonstrations, general elections, or religious processions) would almost invariably entail military involvement. However, the prefects also called upon the army to undertake ordinary crowd management (e.g. during the passage of French or foreign VIPs through the region, for the parades on Bastille Day, at public executions, cattle shows, or horse races). In a great number of cases, the military authorities had already been contacted by the prefect when a strike or demonstration was announced. Thus, the first steps towards military intervention were taken so early that mayors or industrialists who might have had an interest in obtaining military protection hardly had the time even to ask for it. This indicates that the requisition of the army was not simply a measure taken in situations where the interests of some particular pressure group was at stake, but that it was an administrative measure which became entrenched in ordinary bureaucratic practice.

$6_{0}$ Vincent Wright observes a similar pattern of 'isles of stability' in relation to the difficult post of prefect of the Seine, which was occupied for fifteen years, between 1896 and 1911, by Justin de Selves, and the post of police prefect of Paris, held by Louis Lépine from 1899 to 1913 . Wright (1994, p. 299).

61 Sorlin (1966, pp. 461-164); Wormser (1961, pp. 210-224); Erlanger (1968, pp. 356-357). 
Whilst prefects implemented policing measures despite protests from local groups, successive prefects in Lille and Arras expressed their suspicion and criticism of the intentions behind the policing measures of local authorities or private companies, both when these demanded military protection and when mayors protested against the mobilisation of troops to their community. On the one hand, this attitude was apparent in relation to mayors whose sympathies lay with the labour movement. There was little sympathy within the state administration for trades-unionism, which was about to establish itself outside the control of the politicians in the National Assembly. In particular, the communist Confédération Générale du Travail, with its revolutionary tendencies, was regarded with much suspicion $^{62}$. The prefects therefore saw attempts by socialist mayors to protect strikers from police intervention - and ultimately from military intervention - as an irresponsible policy that put public order seriously at risk ${ }^{63}$.

On the other hand, prefects showed similarly little sympathy or understanding for the particular interests of mine and factory owners. Already in the early $1890 \mathrm{~s}$, the prefects in Lille often complained about companies that seemed to regard the public forces - including the army - as their private security service. The irritation of the prefects at private companies was reinforced by problems of making the private companies, which claimed that their property had been insufficiently protected, cover their share of expenses ${ }^{64}$. The suspicion and irritation of the prefects over local industrialists using the public forces for their own particular interests emerge quite strongly in the accounts provided to the Ministry of the Interior concerning the events at Fourmies in 1891, when fourteen striking workers were killed by military troops. In a report from the special commission that had investigated the incident for the Ministry of the Interior, accusations against the local authorities and industrialists were numerous ${ }^{65}$. The blame for the disorder that had broken out during the May Day demonstrations was, according to the special commission, caused by the intransigent attitude of local industrialists towards their employees. The mayor and municipal counsellors - most of whom were mine or factory owners - were also criticised for using public forces to protect their own property, while showing only a semblance of consideration for the maintenance of public order within the rest of the community ${ }^{66}$. After the turn of the century, complaints about private companies using public forces for particular interests were also repeatedly made by prefects from Nord and Pas-de-Calais during the elaboration of general plans for protection of public order in case of a major strike ${ }^{67}$.

62 Wormser (1961, p. 224); Sorlin (1966, pp. 470-471); Agulhon (1990, p. 219).

63 This became particularly apparent during the turbulent spring of 1906 , when socialist mayors - in particular Basly, mayor of Lens - joined the demonstrations against the military intervention. Wormser (1961, p. 210-214); Rebérioux $(1975$, p. 113). Similarly, the troubles in Southern France over the summer 1907 , showed the opposition from mayors who were sympathetic to the protest movement of the wine growers, and who resigned in great numbers in protest against the military intervention.

64 Departmental Archives, Arras, M.1231. Letter of 22 October 1889 from the prefect of Pas-de-Calais to the senior manager of 'La Compaguie de Béthune'.

65 National Archives Paris (AN), F.7.12527, Report of 14 June 1891 by the Commission spéciale adjointe to the Ministry of the Interior.

66 AN, F.7.12525. Report of 6 May 1891 by the prefect of département Nord to the Ministry of the Interior.

67 AN, F.7.12778-12779 'Mesures à prendre en cas de grève générale des mineurs'. 
To be sure, intervention with military troops in many labour conflicts was obviously to the advantage of the employers, not only to protect the mine or factory installations but also to ensure the access of strike-breakers to the workplace. In a number of the great labour conflicts, the military intervention was aimed at protecting French industry from being brought to a stand-still by a scarcity of energy, transport or communication. However in the majority of labour conflicts, presence of military troops seems to be a side-effect of the prefects' wish for control and need for imposing the legal rights of strike-breakers to continue working rather than active attempts to support the particular interests individual industrialists.

\section{CONCLUSION}

Comparison of the use of military troops as an extended police force in Westphalia and Nord-Pas-de-Calais shows that the extremely frequent calls upon the army in Nord-Pas-de-Calais were not due to difficulties of the French central government and state administration in curtailing municipal authorities' right to request military assistance to municipal police.

By different institutional means, the municipal authorities in Westphalia as well as in Nord-Pas-de-Calais became effectively excluded from the decision-making process whenever the military authorities were involved in the management of local conflicts. In Westphalia, where the state administration generally worked closely with municipal authorities on maintenance of public order, calling upon the army was a measure that the Oberpräsident and Regierungspräsidents were unwilling to implement. In Nord-Pas-de-Calais, the prefects did not include municipal authorities in the planning and implementation of measures to maintain public order. Instead, the prefects strongly tended to bypass the municipal authorities by taking over the entire responsibility for law-and-order measures in all potentially sensitive conflicts. In their implementation of policing measures, the prefects in Nord-Pas-deCalais were just as capable as their Westphalian counterparts of withstanding pressures from local politicians and industrial pressure groups to call upon the army or refrain from sending troops; indeed, measures were often implemented against the explicit wishes of otherwise influential groups and individuals. Finally, even if the policing measures implemented in labour conflicts were clearly to the advantage of the employers, the very frequent use of troops in Nord-Pas-de-Calais could hardly be explained as being due to the particular eagerness on the part of the prefects to accommodate the interests of great industrialists. Like their Westphalian counterparts, the prefects in Nord and Pas-de-Calais were very self-conscious, as the representatives of the State acting as a 'neutral' force between employers and employees.

This brings the focus back to the policies of the French and German government and state administration. If the army was used far more frequently in Nord-Pas-deCalais than in Westphalia, it was successive governments and the French state administrations that were entirely responsible. In neither of the two regions do the policies of policing measures seem to be primarily a response to the wishes of local elites or industrial interests. In Westphalia, the policy of de-militarising the policing of protest and labour conflicts went directly against what industrial elites perceived as their interests. Similarly in Nord-Pas-de-Calais, the frequent use of the army seems to be linked primarily to the need of the state administration to control even 
small-scale unrest and to impose the measures of an allegedly 'neutral' state on conflict between opposing groups in local communities.

\author{
Anja Johansen \\ Clare Hall \\ Herschel Road \\ Cambridge (U.K.) \\ CB3 9AL \\ aj232@cam.ac.uk
}

\title{
REFERENCES
}

Agulhon, M., La République, 1880-1932, Paris, Hachette Pluriel, 1990.

Augustine, D., Arriving in the upper class: the wealthy business elite of Wilhelmine Germany, in Blackbourne, D., Evans, R. Eds., The German Bourgeoisie, London-New York, Routledge, 1993, pp. 47-86.

Berlepsch, H. Frhr. Von, Sozialpolitische Erfahrungen und Erinnerungen, MönchenGladbach, Volksvereins-Verlag, 1925.

Berlière, J.-M., Institution policière en France sous la Troisième République, 1875-1914, Dissertation, University of Bourgogne, 1991.

Berlière, J.-M., Le Préfet Lépine, aux origines de la police moderne, Paris, Denoël, 1993a.

Berlière, J.-M., Du maintien de l'ordre républicain au maintien républicain de l'ordre? Genèse: maintenir l'ordre, 1993b, 12, pp. 6-29.

Berlière, J.-M., Aux origines d'une conception moderne du maintain de l'ordre in Fourmies et les Premier Mai (ed. Madelaine Rebérioux), Paris, Les Éditions de l'Atelier, 1994.

Berlière, J.-M., Le monde des polices en France, Paris, Éditions Complexes, 1996.

Blackbourn, D., The Marpingen Vision: Rationalism, Religion and the Rise of Modern Germany, London, Harper Collins, 1993.

Boll, Arbeitskämpfe und Gewerkschaften in Deutschland, England und Frankreich, Bonn, Verlag J.H.W.Dietz Nachfolger, 1992.

Born, K. E. Staat und Sozialpolitik seit Bismarcks Sturtz: Ein Beitrag Geschichte der innenpolitischen Entwicklung des deutschen Reiches, 1890-1914, Wiesbaden, Franz Steiner, 1957.

Bruneteaux, P., Le désordre de la répression en France, 1871-1921: des conscrits aux gendarmes mobiles, Genèse, 1993,12, pp. 30-46.

Bruneteaux, P., Maintenir l'ordre, Paris, Presses de la FNSP, 1996.

Carrot, G., Le maintien de l'ordre. La France de la fin de l'Ancien Régime jusqu'à 1968, Thèse, Universite de Nice, 1984.

Chapman, B., The Prefects and Provincial France, London, Allen \& Unwin, 1955.

Cooper-Richet, D., Le plan général de protection à l'épreuve de la grève des mineurs du Nord-Pas-de-Calais, (sept-nov.1902), in Vigier, Ph. Ed., Maintien de l'ordre et polices, Paris, Créaphis, 1987, pp. 397-413.

Deist, W., Die Armée in Staat und Gesellschaft 1890-1914 in Militär Staat und Gesellschaft 1890-1914, 1991, (first published 1970) pp. 19-41.

Erlanger, Ph., Clemenceau, Paris, Grasset, 1968.

Funk, A., Polizei und Rechtsstaat: Die Entstehung des Staats-rechtlichen Gewaltsmonopol in Preussen, 1848-1918, Frankfurt am Main, Campus Verlag, 1986. 
Girardet, R., La société militaire dans la France contemporaine 1815-1939, Paris, Plon, 1953.

Haupt, H.-G., Staatsliche Buerokratie und Arbeiterbewegung: Zum Einfluß der Polizei auf die Konstituierung von Arbeiterbewegung und Arbeiterklaße in Deutschland und Frankreich zwischen 1848 und 1880, in Kocka, J. Ed., Arbeiter und Buerger im 19. Jahrhundert. Varianten ihres Verhaeltnisse im europäischen Vergleich, Munich, Beck, 1986, pp. 219-260.

Henning, H., Staatsmacht und Arbeitskampf: Die Haltung der preussischen Innen-verwaltung zum Militäreinsatz während der Bergarbeiterausstände 1889-1912, in Henning, H. Ed., Wirtschafts - und Sozialgeschichtlische Forschungen und Probleme - Festschrift für K.E.Born, Göttingen, Vandenhoeck \& Ruprecht, 1987, pp.139-174.

Hobsbawm, E., The Age of Empire, 1875-1914, London, Abacus, (first published 1987), 1997.

Jauffret, J.-Ch., Armée et pouvoir politique: la question des troupes spécialisés chargées du maintien de l'ordre en France de 1871 à 1914, Revue Historique 1983, 270, pp. 97-144.

Jessen, R., Polizei im Industrierevier, Göttingen, Vandenhoeck \& Ruppreckt, 1991.

Jessen, R., Unternehmerherrschaft und staatliches Gewaltmonopol. Hüttenpoliziten und Zechenvehren im Ruhrgebiet 1870-1914, in Lüdtke, A. Ed., Sicherheit und Wohlfart: Polizei, Gesellschaft und Herrschaft im 19. und 20. Jahrhundert, Frankfurt am Main: Suhrkamp, 1992, pp.161-186.

Johansen, A., Bureaucrats, Generals and the Domestic Use of Military Troops: Patterns of Civil-Military Co-operation concerning Maintenance of Public Order in French and Prussian Industrial Areas, 1889-1914, Dissertation, European University Institute, Florence, 1998.

Julliard, J. Clemenceau briseur de grève Paris, Julliard, 1965.

Kaudelka-Hanisch, K., The titled businessman: Prussian commercial councellors in the Rhineland and Westphalia during the nineteenth century, in Blackbourn, D., Evans, R. Eds., The German Bourgeoisie, London - New York, Routledge, 1993, pp. 87-114.

Klückmann, H., Requisition und Einsatz bewaffneter Macht in der deutschen Verfassungsund Militärgeschichte, Militärgeschichtliche Mitteilung, 1978, 1, pp. 7-50.

Lüdtke, A., 'Gemeinwohl', Polizei und 'Festungspraxis'. Staatsliche Gewaltsamkeit und innere Verwaltung in Preussen, 1815-1850, Göttingen, Vandenhoeck \& Ruprecht, 1982.

Moscovici, S. L'âge des foules, Paris, Fayard, 1981.

Perrot, M., Les ouvriers en grève. France 1871-1890, Thèse, Université de Lille, 1975.

Pierenkemper, T., Die Westphälischen Schwerindustriellen 1852-1913. Sociale Struktur und unternehmerischer Erfolg, Göttingen, Vandenhoeck \& Ruprecht, 1979.

Rebérioux, M., La République radicale? 1898-1914, Paris, Éditions du Seuil, 1975.

Serman, W., Les officiers francais dans la nation, 1848-1914, Paris, Aubier, 1982.

Siweck-Pouydesseau, J., Le corps préfectoral sous la Troisième et la Quatrième Républiques, Paris, Armand Colin, 1969.

Sorlin, P., Waldeck-Rousseau, Paris, Armand Colin, 1966.

Spencer, E. G., Management and Labor in Imperial Germany. Ruhr industrialists a as employers, 1896-1914, New Brunswick, New Jersey, Rutgers University Press, 1984.

Spencer, E. G., Police-military relations in Prussia, 1848-1914, Journal of Social History 1985,19 , pp. 305-317.

Spencer, E. G., Police and the Social Order in German Cities : the Düsseldorf District, 18481914, Northern Illinois University Press, 1992.

Tilly, Ch., La France conteste de 1600 à nos jours Paris, Fayard, 1986. 
Tilly Ch., Tilly, L. \& Tilly, R., The Rebellious Century 1830-1930, Massachusetts, Harvard University Press, 1975.

Waldersee, A. Graf von, Denkwürdigkeiten des General-Feldmarchalls Alfred von Waldersee, Berlin, E.S.Mittler \& Sohn, 1922.

Waldersee, A. Graf von, Aus dem Briefwechsel des General-Feldmarschalls Alfred Graf von Waldersee, Berlin, E.S.Mittler \& Sohn, 1927.

Wormser, G., La République de Clemenceau, Paris, PUF, 1961.

Wright, V., La réserve du corps préfectoral, in Birnbaum, P. Ed., La France de l'affaire Dreyfus, Paris, Gallimard, 1994, pp. 290-308. 